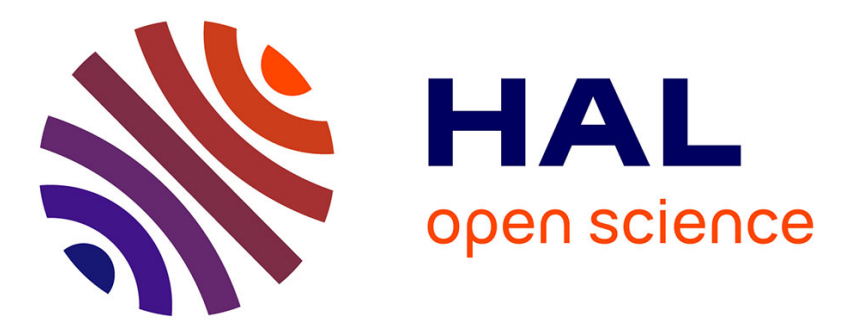

\title{
Photothermally active cryogel devices for effective release of antimicrobial peptides: on-demand treatment of infections
}

Laura Chambre, Léa Rosselle, Alexandre Barras, Duygu Aydin, Aleksandra Loczechin, Suzan Gunbay, Rana Sanyal, Nadia Skandrani, Nils Metzler-Nolte, Julia Elisabeth Bandow, et al.

\section{To cite this version:}

Laura Chambre, Léa Rosselle, Alexandre Barras, Duygu Aydin, Aleksandra Loczechin, et al.. Photothermally active cryogel devices for effective release of antimicrobial peptides: on-demand treatment of infections. ACS Applied Materials \& Interfaces, 2020, 12 (51), pp.56805-56814. 10.1021/acsami.0c17633 . hal-03089813

\section{HAL Id: hal-03089813 https://hal.science/hal-03089813}

Submitted on 24 Sep 2021

HAL is a multi-disciplinary open access archive for the deposit and dissemination of scientific research documents, whether they are published or not. The documents may come from teaching and research institutions in France or abroad, or from public or private research centers.
L'archive ouverte pluridisciplinaire HAL, est destinée au dépôt et à la diffusion de documents scientifiques de niveau recherche, publiés ou non, émanant des établissements d'enseignement et de recherche français ou étrangers, des laboratoires publics ou privés. 


\title{
Photothermally Active Cryogel Devices for Effective Release of Antimicrobial Peptides: On-Demand Treatment of Infections
}

\author{
Laura Chambre, ${ }^{\text {II }}$ Léa Rosselle, ${ }^{\text {II }}$ Alexandre Barras, Duygu Aydin, Aleksandra Loczechin, Suzan Gunbay, \\ Rana Sanyal, Nadia Skandrani, Nils Metzler-Nolte, Julia Elisabeth Bandow, Rabah Boukherroub, \\ Sabine Szunerits,* and Amitav Sanyal*
}

\begin{abstract}
There has been significant interest in the use of peptides as antimicrobial agents, and peptide containing hydrogels have been proposed as biological scaffolds for various applications. Limited stability and rapid clearance of small molecular weight peptides pose challenges to their widespread implementation. As a common approach, antibacterial peptides are physically loaded into hydrogel scaffolds, which leads to continuous release through the passive mode with spatial control but provides limited control over drug dosage. Although utilization of peptide covalent linkage onto hydrogels addresses partially this problem, the peptide release is commonly too slow. To alleviate these challenges, in this work, maleimidemodified antimicrobial peptides are covalently conjugated onto furan-based cryogel (CG) scaffolds via the Diels-Alder cycloaddition at room temperature. The furan group offers a handle for specific loading of the peptides, thus minimizing passive and burst drug release. The porous nature

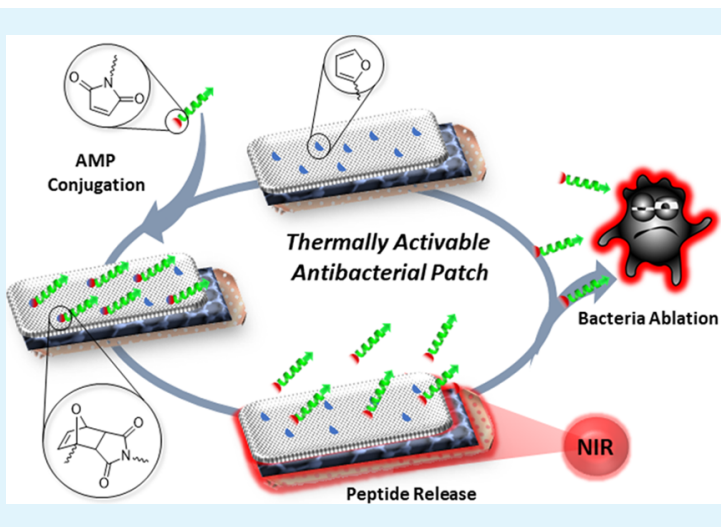
of the CG matrix provides rapid loading and release of therapeutic peptides, apart from high water uptake. Interfacing the peptide adduct containing a CG matrix with a reduced graphene oxide-modified Kapton substrate allows "on-demand" photothermal heating upon near-infrared (NIR) irradiation. A fabricated photothermal device enables tunable and efficient peptide release through NIR exposure to kill bacteria. Apart from spatial confinement offered by this CG-based bandage, the selective ablation of planktonic Staphylococcus aureus is demonstrated. It can be envisioned that this modular "on-demand" peptide-releasing device can be also employed for other topical applications by appropriate choice of therapeutic peptides.
\end{abstract}

\section{INTRODUCTION}

Peptide-containing biomaterials find widespread applications ranging from therapeutics, tissue engineering to wound healing. ${ }^{1-4}$ Indeed, despite the large panel of antibiotics available for the treatment of infectious diseases, the increasing prevalence of bacteria strains that are resistant to conventional antibiotics makes research for alternative therapeutic options timely. ${ }^{5}$ Administration or delivery of peptides has been generally undertaken through encapsulation or conjugation to polymeric materials or using them as building blocks to furnish self-assembled scaffolds. In particular, peptide-based hydrogels have attracted much attention as biological scaffolds for the sustained release of drugs for tissue engineering and wound healing applications. ${ }^{6-8}$ These supramolecular hydrogels are formed simply by dissolving appropriately designed peptides in water and by using stimuli such as $\mathrm{pH}$, enzyme, or temperature in physiological conditions. The ease of preparation allows the encapsulation of cells and/or drugs in the 3D network of the peptide gel through various noncovalent interactions (e.g., hydrogen bonding, $\pi-\pi$ stacking, electrostatic, hydrophobic, or van der Waals interactions).

However, peptide-based hydrogels are mechanically weak and easy to break, making them mostly of interest for the treatment of diseases of damaged tissue via injection. The incorporation of biologically active peptides into synthetic hydrogel scaffolds might be one way to combine the biocompatible nature of the peptide with that of the mechanical rigidity of the loading scaffold. The issues to consider when constructing peptideloaded chemically derived scaffolds are to have a gel support, which allows facile incorporation of the biologically active peptides. At the same time, the design should be such that 
passive and/or burst release is restricted, while preferably, a triggered "on-demand" release can be achieved. ${ }^{9}$

While hydrogels are great platforms as drug cargos and delivery, the focus has shifted in the recent years to utilization of the macroporous member of the hydrogel family, often referred to as cryogels (CGs). ${ }^{10-12}$ The higher porosity of CGs addresses several challenges encountered in traditional hydrogels. Compared to hydrogels, CGs exhibit enhanced drug release due to their higher porosity and swellability. In a recent study, some of us have demonstrated the superior performance of CGs over traditional hydrogels for conjugation and release of anticancer drugs. ${ }^{13}$ In that work, drug release was achieved through cleavage of chemically conjugated therapeutics in a highly acidic environment. While $\mathrm{pH}$-change-triggered release has been widely employed, it is generally slow and relies on the $\mathrm{pH}$ of the environment. External triggers such as light and heat have emerged as attractive alternatives to trigger release of therapeutic agents in an on-demand and controlled fashion. $^{14-17}$

Thermally addressable Diels-Alder (DA) reaction offers a reversible covalent conjugation-deconjugation handle for attachment and release of therapeutic agents. ${ }^{18,19}$ While this reaction has been extensively explored to fabricate crosslinked hydrogel materials, ${ }^{20-24}$ utilization of furan units as a handle to chemical conjugate is not widespread. ${ }^{25-28}$ For instance, maleimide-containing hydrogels have been appended with therapeutic agents and released upon heating by Bowman and co-workers. ${ }^{25,26}$ Likewise, Vieyres et al. reported furan groupcontaining dendrimers, where lipoic acid-modified drugs were conjugated and released upon heating. ${ }^{27}$ While these abovementioned examples employ bulk heating of hydrogels, it can be envisioned that integration of external heating sources, through incorporation of photothermal agents, will address pragmatic challenges associated with heat-triggered therapeutic delivery and offer more opportunities for using a large variety of hydrogels devoid of photothermal properties. Controlled photothermal release of polyethylene glycol (PEG) moieties of PEGylated gold nanorods, formed through a furanmaleimide adduct, was reported by Yamashita et al. ${ }^{28}$

Temperature-guided delivery systems for peptides using photothermal active materials such as reduced graphene oxide (rGO), ${ }^{15,29-33}$ molybdenum disulfide $\left(\mathrm{MoS}_{2}\right),{ }^{34,35}$ and others ${ }^{36,37}$ have been widely used over the years. The synergistic effect through the combination of antibacterial agents and heat on the antibacterial performance and biofilm disruption properties has also been demonstrated in several papers. ${ }^{20,38,39}$ We opted here for a distinct approach for achieving thermalguided release by placing a CG loaded with antimicrobial peptides in close contact to a flexible Kapton substrate coated with $\mathrm{rGO}$, as previously developed for the electrochemical delivery of insulin. ${ }^{40}$ This approach proved to be highly efficient for the release of the maleimide-modified antibacterial peptide from the CG. Indeed, incorporating $\mathrm{rGO}$ into the gel has shown large peptide retention due to $\pi-\pi$ stacking and other interactions of the peptide with the incorporated $\mathrm{rGO}$ sheets. In addition, no direct contact of rGO with the infected skin occurs, and cytotoxicity issues can be ruled out. Moreover this technique can be applied for any type of hydrogel/CG without the need to incorporate any heating-responsive component within their structure.

In this work, the fabrication of a layered device that utilizes a furanyl-functionalized CG is outlined. On-demand release of antimicrobial peptides was achieved by firmly attaching the CG to a Kapton/ rGO interface to conduct thermal stimulation for peptide release (Figure 1). Indeed, the good photothermal

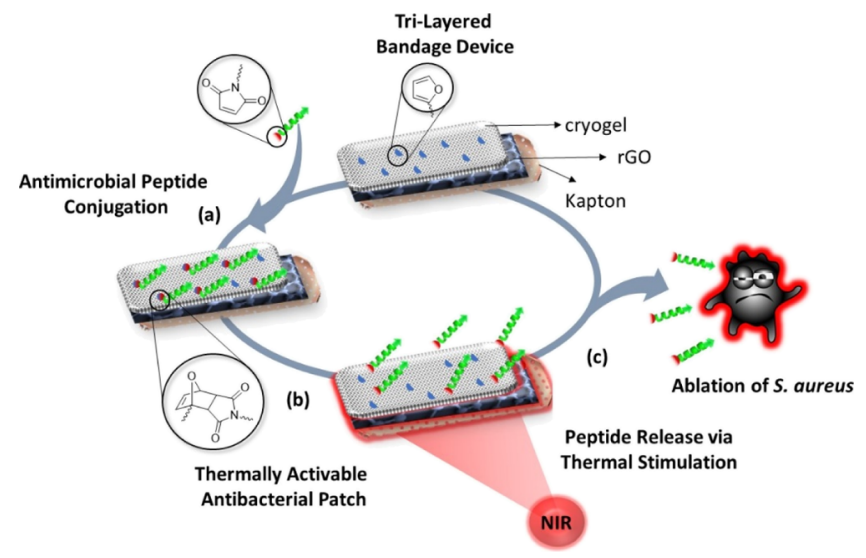

Figure 1. Action of heat on the furan-containing CG device for controlled drug delivery: (a) covalent linkage of maleimide-modified antibacterial peptide via DA reaction at room temperature. (b) Release of maleimide-modified antibacterial peptide at $T>40{ }^{\circ} \mathrm{C}$. (c) Antibacterial action of the peptide against Gram-positive S. aureus. A $\mathrm{rGO} /$ Kapton interface was applied as an external heating source.

properties of rGO allowed increasing the temperature of the attached CGs, which are composed of hydrophilic PEG groups along with furfuryl units. The furfuryl units provide covalent linkage sites for the attachment of maleimide-modified peptides at room temperature using the DA reaction through formation of the thermally labile endo-cycloadduct. Heat activation of the thermally labile furan/maleimide bond using the photothermal properties of an externally attached Kapton/rGO matrix, upon a $980 \mathrm{~nm}$ laser irradiation, results in a retro DA reaction and controlled peptide release. The peptide chosen in this study is a maleimide-modified cationic peptide, maleimideRWRWRWC $-\mathrm{NH}_{2}$ targeting the bacterial membrane of Gram-positive bacteria. ${ }^{41,42}$ Apart from efficient thermally controlled release and bactericidal killing, selective ablation of $S$. aureus in a mixture of bacteria is also demonstrated.

\section{RESULTS AND DISCUSSION}

2.1. Fabrication of Furanyl-Based CGs. A series of furanyl-functionalized CGs were synthesized by changing the ratio of PEG methyl ether methacrylate (PEGMEMA) and furfuryl methacrylate (FuMA) monomers (Figure 2A). The fabrication of the different CGs was carried out at $-13{ }^{\circ} \mathrm{C}$ by exposure to UV light irradiation $(365 \mathrm{~nm})$. 2,2-Dimethoxy-2phenylacetophenone (DMPA) was employed as a photoinitiator, and PEG dimethacrylate (PEGDMA) was used as a cross-linker. Apart from insolubility of the crosslinked material in aqueous and organic solvents, the presence of both monomers was confirmed by FTIR analysis (Figure 2B). In addition to the expected carbonyl and $\mathrm{C}-\mathrm{O}$ ether bond stretchings, distinct peaks belonging to the furan moiety were observable for CG-40.

Analysis of morphology and swelling properties was undertaken to obtain information about porosity and swellability. Increasing the FuMA/PEGMEMA ratio resulted in a decrease of the pore size of the CGs (Figure 2C). In the absence of FuMA monomers, the largest pores were formed $(36.4 \pm 9.6 \mu \mathrm{m})$, decreasing to $13.5 \pm 2.7 \mu \mathrm{m}$ for FuMA/PEGMEMA $=40 / 60$ (Table 1). Likewise, by increasing the hydrophobic character of the CGs upon elevating the amount of FuMA, the swelling 
(A)

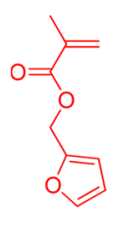

FuMA
PEGMEMA

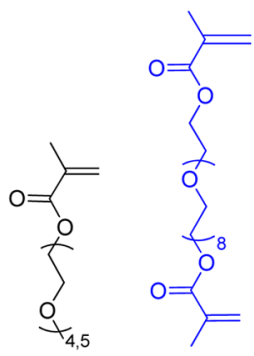

PEGDMA

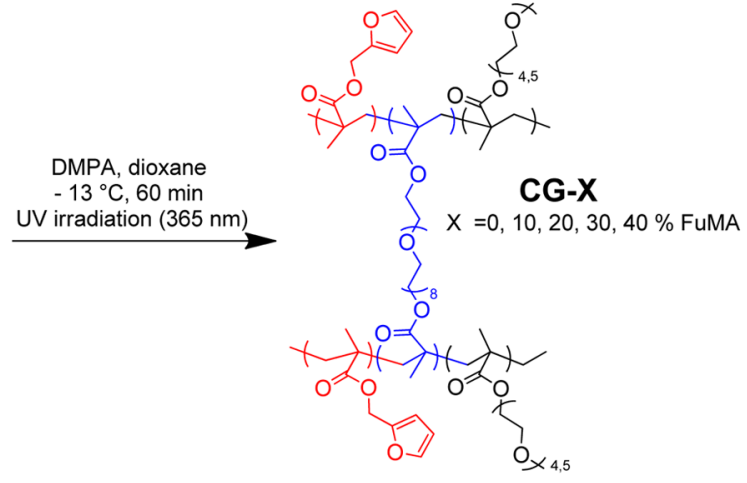

(B)

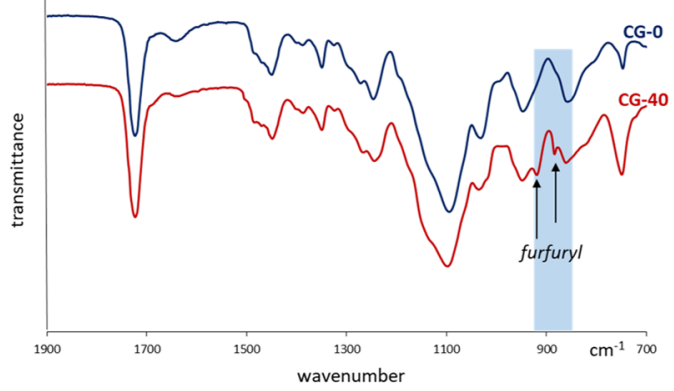

(C)
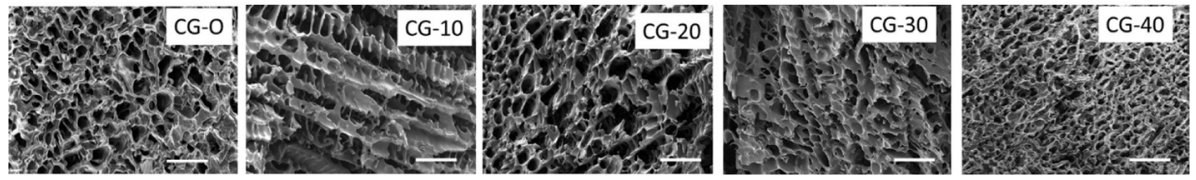

Figure 2. (A) Synthetic route for the fabrication of furan-containing CGs. (B) Representative FTIR spectra of CG-0 and CG-40. (C) SEM images of the formed furan-containing CGs as a function of the percentage of FuMA content; scale bar $=100 \mu \mathrm{m}$.

Table 1. Physical Characteristics of the CGs: Pore Size of the Different CGs Determined from SEM Images ${ }^{a}$

$\begin{array}{ccccc}\text { CG } & \text { FuMA/PEGMEMA } & \begin{array}{c}\text { pore size } \\ {[\mu \mathrm{m}]}\end{array} & \begin{array}{c}\text { swelling } \\ \text { capacity [\%] }\end{array} & \begin{array}{c}\text { loading } \\ \text { capacity [\%] }\end{array} \\ \text { CG-0 } & 0 / 100 & 36.4 \pm 9.6 & 1123 \pm 18 & 0 \\ \text { CG-10 } & 10 / 90 & 26.0 \pm 10.8 & 992 \pm 30 & 8 \pm 2 \\ \text { CG-20 } & 20 / 80 & 23.9 \pm 5.1 & 934 \pm 28 & 21 \pm 2 \\ \text { CG-30 } & 30 / 70 & 16.2 \pm 4.0 & 808 \pm 33 & 32 \pm 2 \\ \text { CG-40 } & 40 / 60 & 13.5 \pm 2.7 & 759 \pm 38 & 40 \pm 2\end{array}$

${ }^{a}$ Swelling capacity determined upon immersion of the CGs into $1 \mathrm{~mL}$ of water for $5 \mathrm{~min}$. Loading capacity of CGs upon immersion for $24 \mathrm{~h}$ into $\mathrm{N}$-(5-fluoresceinyl)maleimide $\left(30 \mu \mathrm{g} \mathrm{mL}^{-1}\right)$.

capacity in water decreased (Table 1). Importantly, all gels reached swelling equilibrium within a few minutes, which ensures rapid transport of therapeutic materials through the matrix (Supporting Information, Figure S1).

2.2. Diels-Alder Reaction-Based Conjugation on CGs. The ability of furfuryl-containing CGs to conjugate maleimidecontaining molecules through the DA cycloaddition reaction was evaluated. $\mathrm{N}$-(5-fluoresceinyl)maleimide, a green fluorescent dye, was used as a model molecule to validate the loading mechanism (Figure 3A). Incubation of CG-40 at room temperature for $24 \mathrm{~h}$ with $\mathrm{N}$-(5-fluoresceinyl)maleimide resulted in the formation of a fluorescent gel (Figure 3B), with a loading efficiency of $40 \pm 2 \%$ (Table 1 ). The amount of loaded dye scales proportionally to the amount of FuMA used for fabricating the CG (Figure 3C and Table 1). The highest loading was indeed achieved for CG-40, and thus, this CG was used in the investigations thereafter. To validate that the dye was covalently bonded to the furan moiety and not simply entrapped and/or nonspecifically adsorbed, the furan-depleted CG gel (CG-0) was immersed for the same time span as the furancontaining analogue, followed by rinsing to remove any unbound dye. As expected, no fluorescence was observed in this case (Figure 3B, left image), thus confirming the role of the furan group in enabling selective attachment of the maleimidecontaining dye.

The equilibrium of the DA cycloaddition reaction is thermally governed. While elevated temperatures induce the reverse reaction, that is, the retro-DA cyclo-reversion, leading to the reformation of maleimide and furan fragments, lower temperatures favor formation of the cycloadduct (Figure 1). Thus, subjecting the polymer networks to increased temperatures should drive the reactions in favor of cyclo-reversion and thus result in a controlled release of the cargo. To increase the temperature of the CG, the CG was heated by a photothermal active heating patch, as schematically outlined in the Supporting 
(A)

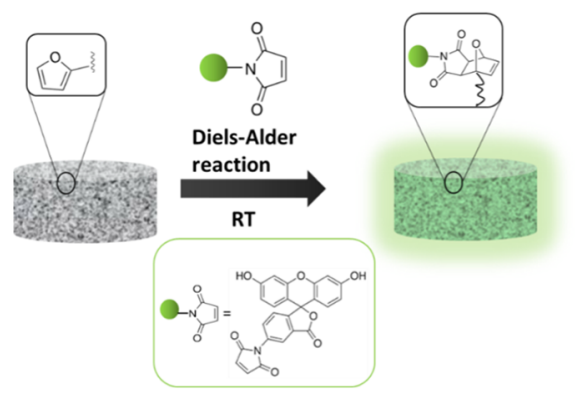

(C)

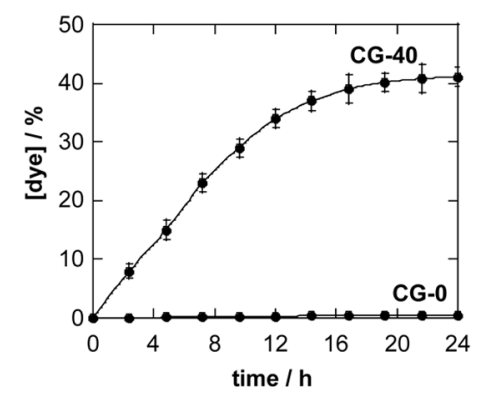

(B)

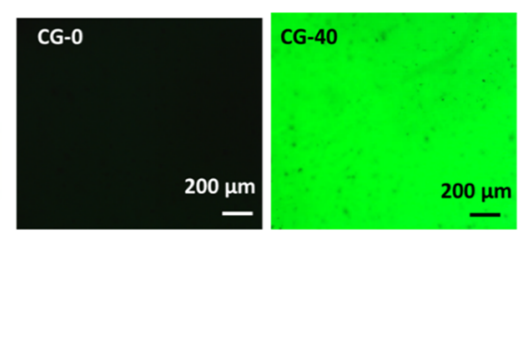

(D)

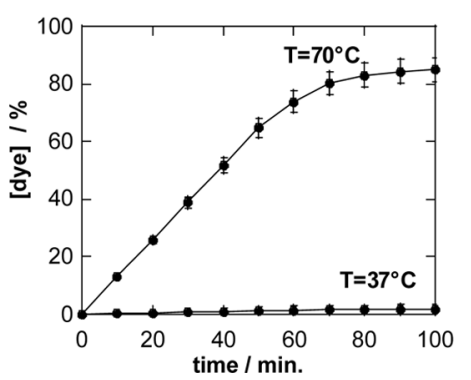

Figure 3. (A) Schematic illustration of furan-free CG-0 (control) and furfuryl-containing CG-40 loading with $N$-(5-fluoresceinyl)maleimide via DA cycloaddition. (B) Fluorescence images of the obtained gels after intense washing to desorb nonspecific linked dye. (C) Uptake kinetics of $N$-(5fluoresceinyl)maleimide at RT upon immersion in a solution of $N$-(5-fluoresceinyl)maleimide $\left(30 \mu \mathrm{g} \mathrm{mL}^{-1}\right)$ for $24 \mathrm{~h}$. (D) Release of $\mathrm{N}$-(5fluoresceinyl)maleimide via retro-DA from CG- 40 at $70{ }^{\circ} \mathrm{C}$ and $37^{\circ} \mathrm{C}$.

Information (Figure S2). The photothermal patch consists of a Kapton substrate coated with a rGO layer (Kapton/rGO). ${ }^{31}$ The heat generated on the Kapton/rGO interface ${ }^{31}$ is indeed sufficient to increase the temperature of the CG when immersed into water to a temperature as high as $70^{\circ} \mathrm{C}$, as recorded with a thermal camera, leading to a heat-triggered release of $\mathrm{N}$-(5fluoresceinyl)maleimide. While at $37^{\circ} \mathrm{C}$, not more than $2 \%$ of the dye was released, increasing the temperature to $70{ }^{\circ} \mathrm{C}$ resulted in an almost complete release of the incorporated dye after $1 \mathrm{~h}$ (Figure 3D). In contrast, upon storing the gel in an aqueous solution at $37^{\circ} \mathrm{C}$, without any thermal activation, only about $2.1 \%$ of the incorporated dye was released (passive release).

2.3. Loading and Release of an Antimicrobial Peptide from CG-40. Motivated by the possibility to load and photothermally release a maleimide-functional dye from a CG40 gel, the efficacy of the CG for loading and releasing of a maleimide-modified antibacterial peptide (Figure 4A) was pursued. The antimicrobial peptide investigated in this work is a maleimide-modified cationic peptide (see the Supporting Information, Figure S3 for the synthetic approach) containing three tryptophan and three arginine units. This small peptide targets the bacterial membrane and inhibits cellular respiration and cell wall synthesis. ${ }^{41,42}$ The maleimide-modified peptide has a preferential antibacterial effect on Gram-positive bacteria with a smaller minimum inhibition (MIC) value for methicillinresistant Staphylococcus aureus ATCC 43300 but only affecting moderately Gram-negative bacteria strains (Table 2).

Peptide loading onto the CG-40 was achieved by immersion at room temperature in an aqueous solution of the peptide (300 $\left.\mu \mathrm{g} \mathrm{mL}^{-1}\right)$. After $5 \mathrm{~h}$ incubation, followed by washing with water to remove unbound maleimide-modified peptide, HPLC analysis of the remaining peptide in solution indicated that about $195 \mu \mathrm{g} \mathrm{mL}^{-1}$ (65\%) of the peptide was chemically integrated into the CG (Figure 4B). Compared to other literature reports, ${ }^{15,43}$ the loading time and amount of maleimide-modified antimicrobial peptide into CG-40 are comparable to that of insulin loading into a PEG-based hydrogel where after $4 \mathrm{~h}, 88 \%$ of insulin was integrated.

Photothermal activation of the CG between 37 and $60{ }^{\circ} \mathrm{C}$ resulted in the antibacterial peptide release (Figure $4 \mathrm{C}$ ) in a temperature-dependent manner. After $10 \mathrm{~min}$, the peptide amount released at $52{ }^{\circ} \mathrm{C}$ accounts for about $33 \mu \mathrm{g} \mathrm{mL}^{-1}$, close to the MIC value of S. aureus ATCC43300 (Table 2Figure S4) The enhanced release rate, observed at higher temperatures, correlates with the increased rate of the retro-DA reaction. Most importantly, insignificant release was observed at $37^{\circ} \mathrm{C}$ due to the chemical linkage between the peptide and the CG. The release can be explained by the excellent light-to-heat conversion performance of the external Kapton/rGO matrix (Figure 4D). On the other hand, the results of a rGO-loaded CG for the release of peptides (Figure S5) indicate that when rGO is present within the CG, peptide release is less efficient. This observation is not linked to an eventual lower heat gradient, but that the peptides have a strong affinity to $\mathrm{rGO}$ which makes its release more difficult.

The temperature image of the Kapton/rGO matrix shows a homogeneous heat distribution with a temperature increase to $52{ }^{\circ} \mathrm{C}$ upon laser irradiation at $980 \mathrm{~nm}$ at a power density of 0.5 $\mathrm{W} \mathrm{cm}^{-2}$ for $10 \mathrm{~min}$. In the case of the Kapton/rGO with attached CG-40, a temperature of $52{ }^{\circ} \mathrm{C}$ was only reached when a laser power of $1.0 \mathrm{~W} \mathrm{~cm}^{-1}$ was applied. The thermal damage to an ex vivo skin tissue was evaluated as skin exposure to temperatures above the physiological temperature over an extended period of time can result in skin tissue damage. ${ }^{44}$ Figure 4E depicts the histological analysis of human skin in contact with the CG-40 before and after heat activation for 10 min using conventional hematoxylin and eosin (H\&E) staining. 
(A)

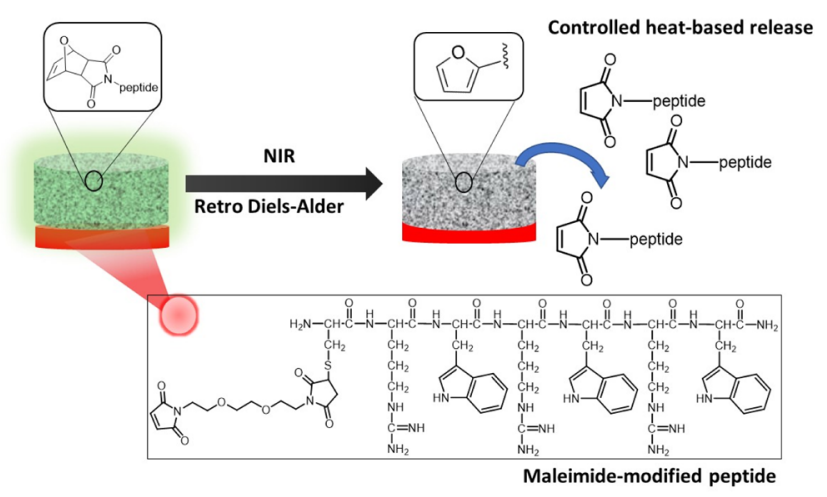

(B)

(C)
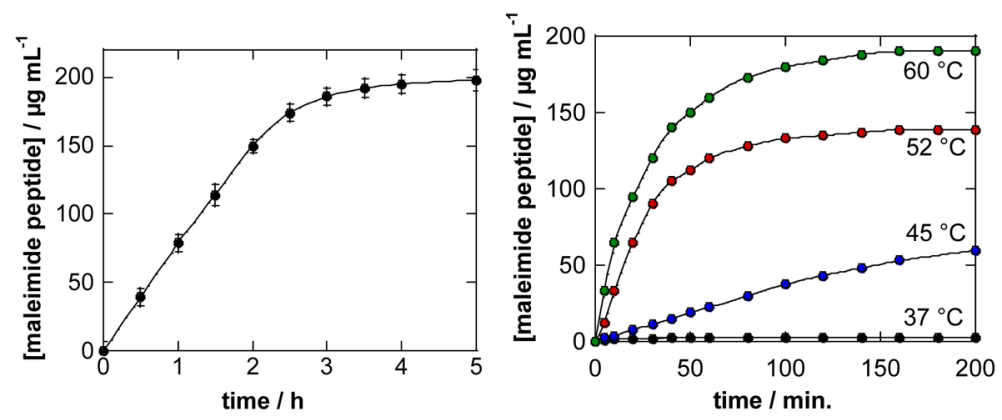

(D)

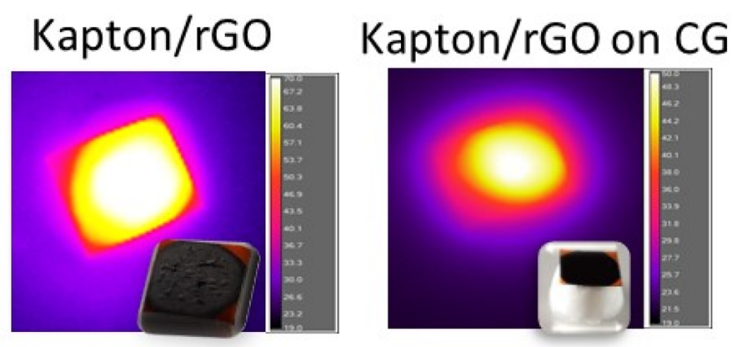

(E)
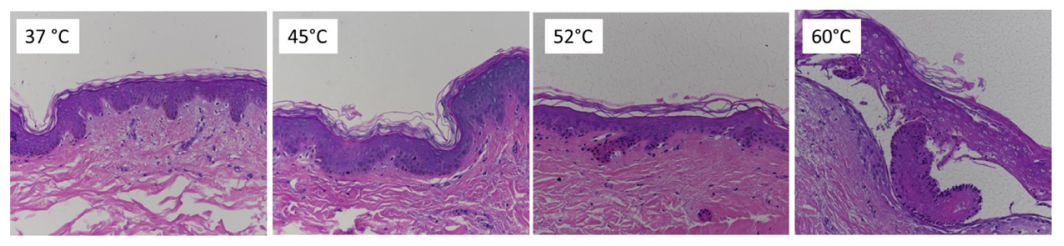

Figure 4. (A) Schematic representation of maleimide-modified antimicrobial peptide release through retro-DA based cleavage at temperature $>40{ }^{\circ} \mathrm{C}$. (B) Loading kinetics of maleimide-modified antimicrobial peptide onto CG-40. (C) Release kinetics at $37{ }^{\circ} \mathrm{C}$ (black), $45^{\circ} \mathrm{C}$ (blue), $52{ }^{\circ} \mathrm{C}$ (red), and $60^{\circ} \mathrm{C}$ (green) of maleimide-modified antimicrobial peptide. (D) Thermal images captured by an infrared (IR) camera (Thermovision A40) of the Kapton/rGO substrate without and with a CG upon NIR illumination at $1 \mathrm{~W} \mathrm{~cm}$. (E) Bright-field micrographs of a histological section of an ex vivo human skin model thermally activated for $10 \mathrm{~min}$ to different final temperatures with a CG-40 loaded with antimicrobial peptide in contact with Kapton/rGO.

Table 2. Minimal Inhibitory Concentration (MIC) of RWRWRWC- $\mathrm{NH}_{2}$ and Maleimide Modified RWRWRWC$\mathrm{NH}_{2}$ on Gram-Negative and Gram-Positive Bacteria Strains

\begin{tabular}{|c|c|c|}
\hline antibacterial drug & $\begin{array}{c}\text { E. coli DCM } \\
30083\left(\mu \mathrm{g} \mathrm{mL}^{-1}\right)\end{array}$ & $\begin{array}{c}\text { S. aureus ATCC } \\
43300\left(\mu \mathrm{g} \mathrm{mL}^{-1}\right)\end{array}$ \\
\hline RWRWRWC- $\mathrm{NH}_{2}$ & 33.0 & 17.3 \\
\hline maleimide-RWRWRWC- $\mathrm{NH}_{2}$ & 57.2 & 34.7 \\
\hline
\end{tabular}

Heating up to $52{ }^{\circ} \mathrm{C}$ for $10 \mathrm{~min}$, normal dermis characteristics are observed and epidermis as well as dermis are unaffected. Increasing the temperature to $60{ }^{\circ} \mathrm{C}$ led, however, to skin damage and was not used in subsequent experiments.

2.4. Bacterial Ablation. The activity of the released antibacterial peptide was assessed on planktonic $S$. aureus using a standard cfu test. Figure 5A clearly shows that the amount of the released peptide at $37^{\circ} \mathrm{C}$ was not sufficient to 
(A)

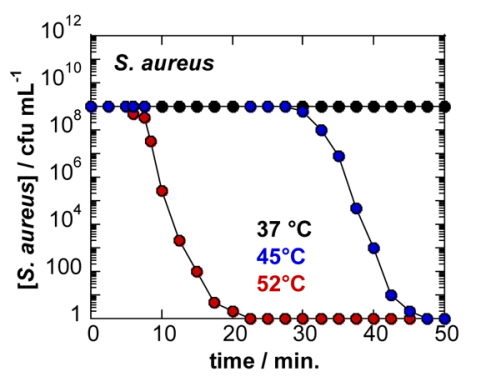

(C)

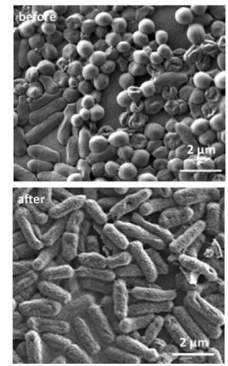

(B)

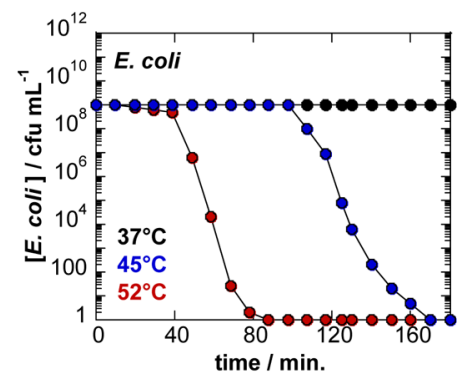

(D)

(E)
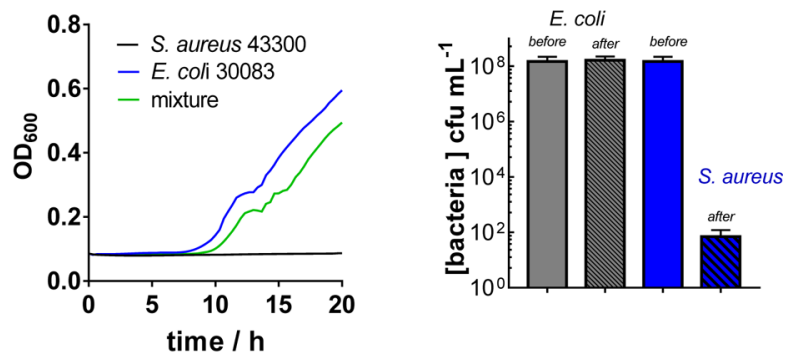

Figure 5. Ablation of S. aureus and E. coli and a mixture of both pathogens: change in the bacteria concentration as a function of time and applied temperature of CG-40 loaded with $197 \mu \mathrm{g} \mathrm{mL}^{-1}$ maleimide-modified antimicrobial peptide for (A) S. aureus ATCC 4330 and (B) E. coli DCM 30083. (C) SEM images of a mixture of S. aureus and E. coli (each $5 \times 10^{5} \mathrm{CFU} \mathrm{mL}^{-1}$ ) before and after treatment with a CG-40 loaded with maleimidemodified antimicrobial peptide and activated at $52{ }^{\circ} \mathrm{C}$. (D) Bacteria cell growth measurements of $S$. aureus, E. coli, and a bacteria mixture in the presence of $35 \mu \mathrm{g} \mathrm{mL}^{-1}$ maleimide-modified antimicrobial peptide. (E) Amounts of viable bacteria of a mixture of S. aureus (blue) and E. coli (black) before and after treatment with a CG-40 loaded with maleimide-modified antimicrobial peptide and activated at $52{ }^{\circ} \mathrm{C}$ for 10 min.

induce $S$. aureus ablation. Heating the CG up to 45 and $52{ }^{\circ} \mathrm{C}$ resulted in a time-dependent release of the peptide. 20 min were required in the case of heating at $45^{\circ} \mathrm{C}$ to reach $30 \mu \mathrm{g} \mathrm{mL}{ }^{-1}$ (close to the MIC value) of the released peptide (Table 2), while increasing the activation temperature to $52{ }^{\circ} \mathrm{C}$ revealed a complete bacterial ablation at around $20 \mathrm{~min}$. In the case of $E$. coli (Figure 5B), a comparable trend as for $S$. aureus was observed. Due to the larger MIC values, higher peptide concentrations were needed and the antibacterial effect was thus shifted on the time scale. In a control experiment, a CG-40 without the antimicrobial peptide was irradiated under the same conditions (Supporting Information, Figure S6). The absence of antimicrobial peptide in the CG-40 achieved a decrease in the bacteria concentration of only $1 \times \log$ at $52^{\circ} \mathrm{C}$, while no change was recorded at $45^{\circ} \mathrm{C}$. The decrease of $1 \times \log$ at $52^{\circ} \mathrm{C}$ was most likely due to the photothermal heating effect. ${ }^{45,46}$

We took advantage of the difference in MIC values for $S$. aureus and E. coli and checked if our approach would allow for selective pathogen ablation. Figure $5 \mathrm{C}$ depicts the scanning electron microscopy (SEM) images obtained from a solution containing S. aureus and E. coli before and after treatment with a CG-40 loaded with the maleimide-modified antimicrobial peptide for $40 \mathrm{~min}$ at $52{ }^{\circ} \mathrm{C}$. One can clearly see the presence of both pathogens in the initial suspension. Thereafter, only $E$. coli strains remained, indicating that $S$. aureus was completely ablated under these conditions. This visual examination was further consolidated by cell growth measurements (Figure 5D) and by bacteria plating (Figure $5 \mathrm{E}$ ) to quantify the number of viable bacteria cells by spotting the bacteria solution on selective agar plates, Chapman and MacConkey, respectively. Bacteria cell growth measurements of $S$. aureus, E. coli, and a bacteria mixture in the presence of $35 \mu \mathrm{g} \mathrm{mL}^{-1}$ maleimide-modified antimicrobial peptide revealed complete $S$. aureus cell growth inhibition, in contrast to E. coli exponential cell growth after $10 \mathrm{~h}$ of incubation (Figure 5D). The mixture exhibited a growth profile comparable to the E. coli bacteria growth curve, with an overall decreased optical density, indicating lower bacteria present, as expected. Viable cell determination also indicated that, in the case of $S$. aureus, a significant decrease in bacterial cell viability was achieved, while no effect was observed on $E$. coli.

To make this approach closer to reality, the biocompatibility of CG-40 and peptide-loaded CG-40 was assessed on HeLa cell line derived from cervical carcinoma from a 31 year old female (Figure S7). No loss in cell viability was observed upon incubation of HeLa cells for 24 and 48 h with CG-40 and CG-40 loaded with maleimide-modified antimicrobial peptide. This can be expected due to the benign nature of the CG components toward cells. Also, lack of toxicity suggests that no residual monomers, which could lead to potential cytotoxicity, are present in the CG matrix. Furthermore, eventual detrimental effects of thermal activation of the peptide-loaded CG-40 on cell viability were determined. Thermal activation of the CG for 10 min at $52{ }^{\circ} \mathrm{C}$ did not induce any change in cell viability.

Finally to provide a first demonstration on how this technology can be applied, an ex vivo wound skin (Figure 6A) was infected with $S$. aureus (Figure 6B) and the wound texture was investigated after treatment with a peptide-loaded CG-40 activated at $52{ }^{\circ} \mathrm{C}$ for $10 \mathrm{~min}$. Infection with $S$. aureus was performed in the wound region of the skin for 3 days and then treated with the peptide-loaded CG-40 via light activation at 52 ${ }^{\circ} \mathrm{C}$ for $10 \mathrm{~min}$. The success of the treatment was followed by a visual inspection of the skin, displaying changes in the color 


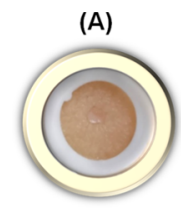

Wounded Ex vivo skin

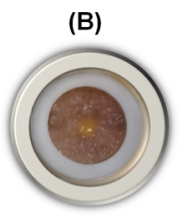

S. aureus infected skin

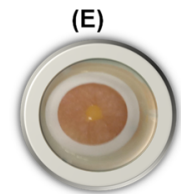

Treated skin peptide loaded CG-40 Not activated

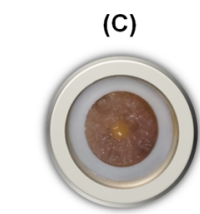

Treated skin CG-40

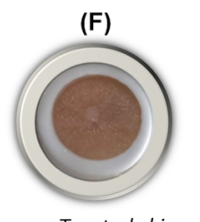

Treated skin

peptide loaded $C G-40$

Heat activated

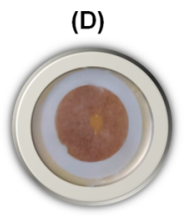

Treated skin CG-40+ heat
Figure 6. Optical images of (A) wounded ex vivo skin, (B) wounded and infected ex vivo skin, and $(\mathrm{C}-\mathrm{F})$ wounded and infected ex vivo skin after treatment: (C) treated skin with CG-40, (D) treated skin with CG-40 and heat activate $\left(52^{\circ} \mathrm{C}\right.$ for $\left.10 \mathrm{~min}\right)$. (E) peptide-loaded CG-40 but not activated. (D) peptide-loaded CG-40 and heat activated $\left(52{ }^{\circ} \mathrm{C}\right.$ for $10 \mathrm{~min}$ ).

upon infection. At day 3, the wound area appeared yellow and had a strong wet aspect, one of the indications of infection. After treatment with only the CG-40 (Figure 6C), no improvement of the aspect of the wound was observed. Heat treatment (Figure 6D) did somehow change the wound appearance showing a more dry aspect. Peptide-loaded CGs but not activated (Figure $6 \mathrm{E})$ also indicated no wound healing effect. However, heat activated and peptide-loaded CG-40 (Figure 6F) resulted in ex vivo skin showing a comparatively dry aspect. These results, though preliminary, suggest that sufficient peptide release occurs to eradicate bacterial infection.

\section{CONCLUSIONS}

A layered device for an on-demand release of an antimicrobial peptide was fabricated and successfully applied to efficiently kill specific bacteria upon photothermal activation. A furancontaining CG matrix allows covalent conjugation of a maleimide-containing bioactive peptide through the DA reaction. An underlying rGO layer coated on Kapton enables photothermal heating of the construct upon exposure to NIR irradiation, which releases the conjugated bioactive agent through the retro DA reaction. The extent of conjugation onto these CGs can be tuned by changing the amount of furan moieties within the CGs, as demonstrated by attachment of a maleimide-containing fluorescent dye. Application of this device for on-demand killing of bacteria was achieved through conjugation of a maleimide-containing antimicrobial peptide. Photothermal release of the peptide from the CG results in the bactericidal effect with selectivity for the Gram-positive $S$. aureus, while no significant effect was observed for the Gramnegative E. coli strain. The designed CGs can be potentially reused through reimmobilization of maleimide peptides, but since these CGs are fairly simple to fabricate, no such need is anticipated. Our findings demonstrate that an effective device can be easily fabricated and employed in a modular fashion to load and on-demand release of an antimicrobial peptide to combat specific bacterial infections.

\section{EXPERIMENTAL SECTION}

4.1. Materials and Characterization. For details see the Supporting Information.

4.2. Fabrication of Furfuryl-Containing CGs. For the synthesis of $10 \%$ FuMA-containing CGs (CG-10), a mixture of PEGMEMA (61.9 mg, $0.206 \mathrm{mmol})$, FuMA (8.6 mg, $0.052 \mathrm{mmol}$ ), PEGDMA (141.7 $\mathrm{mg}, 0.258 \mathrm{mmol})$, and DMPA (3.3 $\mathrm{mg}, 0.01296 \mathrm{mmol}$ ) was added to 1,4 -dioxane $(1.5 \mathrm{~mL})$ in a small vial. The mixture was sonicated for $45 \mathrm{~s}$ to ensure mixing. Then, the vial was cooled to $-13^{\circ} \mathrm{C}$ using a cryostat. The cooled reaction mixture was exposed to UV irradiation for $60 \mathrm{~min}$. The vial was removed from the cryostat and warmed naturally to room temperature. The obtained CGs were rinsed with 1,4-dioxane (three times) and water to remove all unreacted materials. The other CGs (CG-20, CG-30, and CG-40) were prepared in the same manner by only changing the ratio of FuMA/PEGMEMA. The CGs were vacuum dried to yield white cylindrical CGs of $1.5 \mathrm{~cm}$ in diameter and $4-5 \mathrm{~mm}$ in thickness. For fabrication of the sample of rGO-incorporated furfuryl-containing CG, the exact same procedure was followed in the presence of 2 wt $\%$ rGO in the polymerization mixture.

4.3. Synthesis of Maleimide-Modified Peptides. 4.3.1. Synthesis of $R W R W R W C-\mathrm{NH}_{2}$. The peptide RWRWRWC- $\mathrm{NH}_{2}$ was synthesized manually by means of the Fmoc/tBu protocol on an FmocRink amide resin $(0.74 \mathrm{mmol} / \mathrm{g})$ yielding C-terminal amide after cleavage. Solid-supported reactions were undertaken in plastic syringes $(10 \mathrm{~mL})$ with a porous polypropylene disc filter. The resin was swollen for $1 \mathrm{~h}$ in DMF, and the Fmoc protecting group was removed by adding $20 \%$ solution of piperidine in DMF $(3 \mathrm{~mL}, 2 \times 10 \mathrm{~min})$. After removal of the solution, the resin was washed with DMF $(3 \times 2 \mathrm{~min}, 3 \mathrm{~mL})$, IPA $(3 \times 2 \mathrm{~min}, 3 \mathrm{~mL})$, and DCM $(3 \times 2 \mathrm{~min}, 3 \mathrm{~mL})$, and the successful deprotection was confirmed by the Keiser test. Coupling of each amino acid (4 equiv) was achieved by addition of 2 -( $1 H$-benzotriazole- 1 -yl)1,1,3,3-tetramethylaminium tetrafluoroborate (TBTU, 4 equiv), 1hydroxybenzotriazole hydrate (HOBt, 4 equiv), and $\mathrm{N}, \mathrm{N}$-diisopropylethylamine (DiPEA, 8 equiv) in DMF $(3 \mathrm{~mL})$ to the resin. The suspension was shaken at room temperature for $90 \mathrm{~min}$. Solvents and reagents were removed by filtration, and the resin was washed with DMF, IPA, and DCM. The successful coupling was confirmed by the Keiser test (in case of incompletion of the reaction, the coupling was repeated). The Fmoc protecting group was cleaved in order to enable attachment of the next amino acid. Subsequently, the cycle of washing, deprotection was repeated. After the sequence was finished, the Fmoc protecting group was removed, and resin was washed and dried in vacuo. Amino acids used during the synthesis were side chain protected with the BOC group (for the Trp), Pbf (in the case of Arg), and Trt (for Cys). The protecting groups were removed during cleavage of the peptide from the resin with a treatment of TFA/TIS/EDT $(95: 2,5: 2,5$ $\mathrm{v} / \mathrm{v} / \mathrm{v}, 2 \mathrm{~mL} \times 3 \mathrm{~h}$ ). The peptide was precipitated in a mixture of cold $\mathrm{Et}_{2} \mathrm{O} /$ hexane $(20 \mathrm{~mL}, 1: 1 \mathrm{v} / \mathrm{v})$. The supernatant was removed, and the peptide was washed several times with $\mathrm{Et}_{2} \mathrm{O} /$ hexane to be further dispersed in water with the addition of acetonitrile, lyophilized, and purified by a semi-preparative HPLC system with a photo diode arrays (PDA) detector using NUCLEODUR $100-5 \mathrm{C} 18 \mathrm{ec}$ reversed phase column $(125 \times 10 \mathrm{~mm})$ using buffer $\mathrm{A}\left(\mathrm{H}_{2} \mathrm{O} / \mathrm{TFA} 100: 0.1 \mathrm{v} / \mathrm{v}\right)$ and buffer B (MeCN/TFA 100:0.1 v/v) as the mobile phase. The flow rate was set up at $5 \mathrm{~mL} / \mathrm{min}$. Electron spray ionization mass spectra were obtained on an Esquire 6000 mass spectrometer (Bruker). LC-MS analysis confirmed peptide formation $(\mathrm{m} / z=525.0)$.

4.3.2. Functionalization of $\mathrm{RWRWRWC}-\mathrm{NH}_{2}$ Peptide with Maleimide Function. To a small vial containing $100 \mu \mathrm{L}$ of DMF, $\mathrm{BM}(\mathrm{PEG})_{2}(0.81 \mathrm{mg}, 2.62 \mu \mathrm{mol})$ and peptide RWRWRWC- $\mathrm{NH}_{2}(1$ $\mathrm{mg}, 0.871 \mu \mathrm{mol})$ are mixed together. The reaction mixture was stirred overnight at $24{ }^{\circ} \mathrm{C}$. The next day, the solution was precipitated in cold ether and centrifuged at $13,000 \mathrm{rpm}$ for $5 \mathrm{~min}$ to obtain the desired peptide-maleimide (73\%). LCMS analysis revealed the successful conjugation $(m / z=727.0)$ (Figure $S 6)$.

4.4. Conjugation of Furan-CCG with Maleimide Ligands. 4.4.1. Conjugation of $\mathrm{N}$-(5-Fluoresceinyl) Maleimide. A solution of $\mathrm{N}$ (5-fluoresceinyl) maleimide in PBS $\left(30 \mu \mathrm{g} \mathrm{mL}^{-1}\right)$ was loaded into the CG $(30 \mathrm{mg})$ and allowed to react for $24 \mathrm{~h}$ at room temperature. Any 
unbound dye was washed with PBS. Solution of PBS was analyzed by fluorescence to ensure total removal of the dye.

4.4.2. Conjugation of Maleimide-Functionalized Antibacterial Peptides. Maleimide-modified peptide $\left(1 \mu \mathrm{L}, 500 \mu \mathrm{g} \mathrm{mL}^{-1}\right.$ in water $)$ was loaded into CG-40 (30 mg) for $24 \mathrm{~h}$ at room temperature. Any unbound peptide was washed with water. Solution of water was analyzed by UV to ensure total removal of free peptide.

4.5. Photothermal Release. 4.5.1. Preparation of Photothermal Heating Kapton/rGO Substrates. Kapton foils $\left(10 \times 10 \mathrm{~mm}^{2}\right)$ were sequentially cleaned in an ultrasonic water bath, first with acetone (30 $\mathrm{min})$, followed with isopropanol $(10 \mathrm{~min})$ and then dried under a gentle flow of nitrogen. Thereafter, the Kapton foils were coated with rGO by drop-casting $(100 \mu \mathrm{L})$ three times. Samples were left for drying at room temperature for several hours before use.

4.5.2. Photothermal Release Conditions. Release experiments were undertaken in PBS buffer $(1 \mathrm{~mL})$. The CG was irradiated with a continuous mode laser (Gbox model, Fournier Medical solution) with an output light at $980 \mathrm{~nm}\left(1 \mathrm{~W} \mathrm{~cm}^{-2}\right)$ for various time intervals $(1-60$ min). An IR camera (Thermovision A40) was used to capture the thermal images and processed using ThermaCam Researcher Pro 2.9 software. The amount of antibiotic released was determined by HPLC. The quantity of $\mathrm{N}$-(5-fluoresceinyl) maleimide released was evaluated by fluorescence spectroscopy.

4.6. Biological Assays. 4.6.1. Cytotoxicity Assay. The HeLa cells, derived from cervical carcinoma from a 31 year old female (ATCC CCL-2, ECACC, Sigma-Aldrich, Saint-Quentin Fallavier, France), were cultured and maintained in Dulbecco's Modified Eagle's medium (Gibco) supplemented with $10 \%$ fetal bovine serum (Gibco) and $1 \%$ penicillin-streptomycin (Gibco) in a humidified incubator at $37^{\circ} \mathrm{C}$ and $5 \% \mathrm{CO}_{2}$. Cells were seeded at a density of $10^{5}$ cells/well in a 24 -well plate and grown for $24 \mathrm{~h}$ before the start of the assay. The culture medium was replaced with a fresh medium that contains the CGs (10 $\mathrm{mg}$ ). After $24 \mathrm{~h}$, the old medium was removed and cells were washed with PBS. The cell viability of CG-40 was evaluated using the resazurin cell viability method. Briefly, $1 \mathrm{~mL}$ of the resazurin solution $(11 \mu \mathrm{g}$ $\mathrm{mL}^{-1}$ ) in complete medium was added to each well containing the gel and the plate was incubated for $4 \mathrm{~h}$ in the humidified incubator. The fluorescence emission of each well was measured at $593 \mathrm{~nm}(20 \mathrm{~nm}$ bandwidth) with an excitation at $554 \mathrm{~nm}$ (18 nm bandwidth) using a Cytation 5 Cell Imaging Multi-Mode Reader (BioTek Instruments SAS, France). Each condition was replicated three times, and the mean fluorescence value of nonexposed cells was taken as $100 \%$ cellular viability.

4.6.2. Bacteria. E. coli DSM 30083 and S. aureus ATCC 43300 were used in this work. Three to five morphologically similar colonies from fresh agar plates were transferred into a sterile tube containing sterile broth. The bacteria were incubated overnight at $37^{\circ} \mathrm{C}$. The next day, $\mathrm{OD}_{600}$ of the overnight culture was adjusted to an $\mathrm{OD}_{600}$ of 0.1 and was grown to a mid-log phase. After preparing the inoculum at a concentration of $5 \times 10^{5} \mathrm{CFU} / \mathrm{mL}$, the bacterial suspension was used within $30 \mathrm{~min}$ to avoid greater changes in cell concentrations.

4.6.3. Determination of Minimal Inhibitory Concentration. The minimal inhibitory concentration (MIC) values against E. coli DSM 30083 and S. aureus ATCC 43300 were assessed. MIC values were determined in a microdilution assay. Briefly, the peptide and the peptide conjugate were dissolved in DMSO at a concentration of 10 $\mathrm{mg} / \mathrm{mL}$. Serial dilutions were prepared in Mueller-Hinton broth, inoculated with $5 \times 10^{5} \mathrm{CFU} / \mathrm{mL}$ and incubated for $16 \mathrm{~h}$ at $37^{\circ} \mathrm{C}$. Inoculated medium without peptide or conjugate served as a growth control, and uninoculated medium served as sterile control. The lowest concentration that prevented visible growth was reported as MIC value.

4.6.4. Determination of Bacterial Cell Viability. The antibacterial activity of released antibacterial peptide was evaluated using E. coli and $S$. aureus strains by cell growth measurements based on the optical density at $600 \mathrm{~nm}$ and by plating methods to quantify the viable cell number. Briefly, the bacterial cells were inoculated in LB broth (E. coli) and Mueller-Hinton broth (S. aureus) in the presence of different concentrations of released peptide at $37^{\circ} \mathrm{C}$ for $6 \mathrm{~h}$ and the growth was monitored by measuring the absorbance at $600 \mathrm{~nm}$. A 10 -fold serial dilution of the bacterial solutions in medium was spotted in $10 \mu \mathrm{L}$ aliquots on LB-agar (E. coli) and Mueller-Hinton agar (S. aureus). Colony counting after overnight incubation at $37^{\circ} \mathrm{C}$ allowed reading out the initial and final concentrations of viable bacteria in $\mathrm{cfu} \mathrm{mL}^{-1}$. All experiments were performed in triplicate.

4.6.5. Selective Pathogen Ablation. The selectivity of maleimideconjugated peptide was evaluated using S. aureus 43300 and E. coli DSM 30083 strains by SEM imaging, cell growth measurements based on the optical density at $600 \mathrm{~nm}$, and by plating methods to quantify the viable

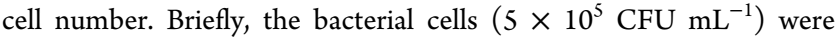
inoculated in Mueller-Hinton broth in the presence of the maleimideconjugated peptide $\left(32 \mu \mathrm{g} \mathrm{mL}^{-1}\right)$ at $37^{\circ} \mathrm{C}$ for $20 \mathrm{~h}$ and the growth was monitored by measuring the absorbance at $600 \mathrm{~nm}$. A 10 -fold serial dilution of the bacterial solutions in medium was spotted in $10 \mu \mathrm{L}$ aliquots on selective agar plates (Chapman and Mac Conkey). Cfu $\mathrm{mL}^{-1}$ were determined after overnight incubation at $37^{\circ} \mathrm{C}$.

4.7. Skin Sampling and Processing. Ready-to-use ex vivo human skin samples were provided by Genoskin (France) in an appropriate skin culture medium without antibiotics in perfused chambers for maintaining tissue survival and preventing cell death and necrosis. Human skin biopsies, containing the three layers of the skin, epidermis, dermis, and hypodermis with the underneath fat tissue (HypoSkin), were collected from abdominal surgery with the informed consent of the individual donors, authorized by the French Ministry of Research (AC-2017-2897, 12 Oct 2017) and approved by the French Ethical Committee (Comité de Protection des Personnes). The skin explants were embedded in a gel-like matrix with the epidermal surface left in direct contact with the air. To generate a wound ( $2 \mathrm{~mm}$ in diameter), a defect of controlled diameter was induced to remove all the epidermis and the upper part of the dermis. A silicon ring was adhered on the skin surface to prevent lateral bacteria leakage. The system was mounted into cell culture inserts and maintained in standard cell culture conditions. S. aureus ATCC 43300 was used to infect the wounds by

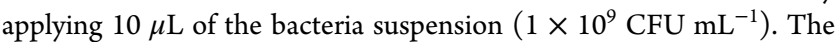
skin culture medium was refreshed every day for each sample. After 3 days of infection, skins were treated with the CG by placing it on the top of the infected wound and heating at $52{ }^{\circ} \mathrm{C}$ for $10 \mathrm{~min}$.

4.8. Skin Staining. For skin staining experiments, an ex vivo human skin model (HypoSkin, Genoskin SAS, Toulouse, France) was used. The CGs were deposited onto the skin and irradiated for $10 \mathrm{~min}$ at 0.5 , 0.7 , and $1 \mathrm{~W} \mathrm{~cm}^{-2}$. Part of the skin was then fixed with formaldehyde (4\%), embedded in paraffin and sectioned ( $5 \mu \mathrm{M}$ pieces in thickness). Tissue sections were stained with $H \& E$ to observe the tissue structure.

\section{ASSOCIATED CONTENT}

\section{sI Supporting Information}

Swelling behavior of different CGs; setup for the local heating of the drug-loaded CG and photothermal heating curves; formation and structure of maleimide-conjugated antimicrobial peptide; release kinetics of rGO-loaded CG; SEM image of rGO-loaded CG-40; loading and release kinetics of maleimide-modified antimicrobial peptide onto rGO-loaded CG-40; changes in bacteria concentrations as a function of time and applied temperature to CG-40; cell viability for 24 and 48 h of CG-40, CG-40 loaded with antimicrobial peptide without and with heat activation at $52{ }^{\circ} \mathrm{C}$ for $10 \mathrm{~min}$; LCMS characterization of the maleimide-conjugated antimicrobial peptide; and experimental section details (materials, swelling of CGs, characterization methods, and quantification of loading and release) 


\section{AUTHOR INFORMATION}

\section{Corresponding Authors}

Amitav Sanyal - Department of Chemistry and Center for Life Sciences and Technologies, Bogazici University, Istanbul 34342, Turkey;

Phone: +902123597613; Email: amitav.sanyal@

boun.edu.tr

Sabine Szunerits - Univ. Lille, CNRS, Centrale Lille, Univ. Polytechnique Hauts-de-France, UMR 8520-IEMN, Lille F59000, France;

Phone: +33 (0)3 625317 25; Email: sabine.szunerits@ univ-lille.fr

\section{Authors}

Laura Chambre - Department of Chemistry, Bogazici University, Istanbul 34342, Turkey;

Léa Rosselle - Univ. Lille, CNRS, Centrale Lille, Univ. Polytechnique Hauts-de-France, UMR 8520-IEMN, Lille F59000, France; TISSUEAEGIS SAS, Dijon 21000, France

Alexandre Barras - Univ. Lille, CNRS, Centrale Lille, Univ. Polytechnique Hauts-de-France, UMR 8520-IEMN, Lille F59000, France;

Duygu Aydin - Department of Chemistry, Bogazici University, Istanbul 34342, Turkey

Aleksandra Loczechin - Univ. Lille, CNRS, Centrale Lille, Univ. Polytechnique Hauts-de-France, UMR 8520-IEMN, Lille F-59000, France; Inorganic Chemistry I - Bioinorganic Chemistry, Ruhr University Bochum, 44801 Bochum, Germany

Suzan Gunbay - Department of Chemistry, Bogazici University, Istanbul 34342, Turkey

Rana Sanyal - Department of Chemistry and Center for Life Sciences and Technologies, Bogazici University, Istanbul 34342, Turkey; RS Research, Istanbul 34912, Turkey;

Nadia Skandrani - TISSUEAEGIS SAS, Dijon 21000, France Nils Metzler-Nolte - Inorganic Chemistry I - Bioinorganic Chemistry, Ruhr University Bochum, 44801 Bochum, Germany;

Julia Elisabeth Bandow - Applied Microbiology, Faculty of Biology and Biotechnology, Ruhr University Bochum, 44801 Bochum, Germany

Rabah Boukherroub - Univ. Lille, CNRS, Centrale Lille, Univ. Polytechnique Hauts-de-France, UMR 8520-IEMN, Lille F59000, France;

\section{Author Contributions}

II L.C. and L.R. authors contributed equally.

\section{Notes}

The authors declare no competing financial interest.

\section{ACKNOWLEDGMENTS}

Financial support from the Centre National de la Recherche Scientifique (CNRS), the University of Lille, the Hauts-deFrance region, the CPER "Photonics for Society", the Agence Nationale de la Recherche (ANR), and the EU union through the Marie Sklodowska-Curie action (H2020-MSCA-RISE-2015, PANG-690836) are acknowledged.

\section{REFERENCES}

(1) Hosoyama, K.; Lazurko, C.; Muñoz, M.; McTiernan, C. D.; Alarcon, E. I. Peptide-Based Functional Biomaterials for Soft-Tissue Repair. Front. Bioeng. Biotechnol. 2019, 7, 205.

(2) Hamley, I. W. Small Bioactive Peptides for Biomaterials Design and Therapeutics. Chem. Rev. 2017, 117, 14015-14041.

(3) Yadav, N.; Chauhan, M. K.; Chauhan, V. S. Short To Ultrashort Peptide-Based Hydrogels As A Platform For Biomedical Applications. Biomater. Sci. 2020, 8, 84-100.

(4) Zong, J.; Cobb, S. L.; Cameron, N. R. Peptide-Functionalized Gold Nanoparticles: Versatile Biomaterials For Diagnostic And Therapeutic Applications. Biomater. Sci. 2017, 5, 872-886.

(5) Fox, J. L. Antimicrobial Peptides Stage A Comeback. Nat. Biotechnol. 2013, 31, 379-382.

(6) Yadav, N.; Chauhan, M. K.; Chauhan, V. S.; Chauhan, V. S. Short To Ultrashort Peptide-Based Hydrogels As A Platform For Biomedical Applications. Biomater. Sci. 2020, 8, 84-100.

(7) Li, J.; Xing, R.; Bai, S.; Yan, X. Recent Advances Of SelfAssembling Peptide-Based Hydrogels For Biomedical Applications. Soft Matter 2019, 15, 1704-1715.

(8) Jiang, L.; Xu, D.; Sellati, T. J.; Dong, H. Self-Assemblyt Of Cationic Multidomaine Peptide Hydrogels: Supermolecualr Nanostructure And Theological Properties Dicated Antimicrobial Activity. Nanoscale 2015, 7, 19160-19169.

(9) Liu, J.; Detrembleur, C.; Mornet, S.; Jérôme, C.; Duguet, E. Design Of Hybrid Nanovehicles For Remotely Triggered Drug Release: An Overview. J. Mater. Chem. B 2015, 3, 6117-6147.

(10) Hoare, T. R.; Kohane, D. S. Hydrogels In Drug Delivery: Progress And Challenges. Polymer 2008, 49, 1993-2007.

(11) Henderson, T. M. A.; Ladewig, K.; Haylock, D. N.; McLean, K. M.; O'Connor, A. J. Cryogels For Biomedical Applications. J. Mater. Chem. B 2013, 1, 2682.

(12) Plieva, F. M.; Galaev, I. Y.; Noppe, W.; Mattiasson, B. Cryogel Applications In Microbiology. Trends Microbiol. 2008, 16, 543-551.

(13) Aydin, D.; Arslan, M.; Sanyal, A.; Sanyal, R. Hooked on Cryogels: A Carbamate Linker Based Depot for Slow Drug Release. Bioconjugate Chem. 2017, 28, 1443-1451.

(14) Wang, Y.; Shim, M. S.; Levinson, N. S.; Sung, H.-W.; Xia, Y. Stimuli-Responsive Materials for Controlled Release of Theranostic Agents. Adv. Funct. Mater. 2014, 24, 4206-4220.

(15) Teodorescu, F.; Oz, Y.; Quéniat, G.; Abderrahmani, A.; Foulon, C.; Lecoeur, M.; Sanyal, R.; Sanyal, A.; Boukherroub, R.; Szunerits, S. Photothermally Triggered On-Demand Insulin Release From Reduced Graphene Oxide Modified Hydrogels. J. Control. Release 2017, 246, 164-173.

(16) Linsley, C. S.; Wu, B. M. Recent Advances In Light-Responsive On-Demand Drug-Delivery Systems. Ther. Delivery 2017, 8, 89-107.

(17) Karimi, M.; Sahandi Zangabad, P.; Ghasemi, A.; Amiri, M.; Bahrami, M.; Malekzad, H.; Ghahramanzadeh Asl, H.; Mahdieh, Z.; Bozorgomid, M.; Ghasemi, A.; Rahmani Taji Boyuk, M. R.; Hamblin, M. R. Temperature-Responsive Smart Nanocarriers for Delivery Of Therapeutic Agents: Applications and Recent Advances. ACS Appl. Mater. Interfaces 2016, 8, 21107-21133.

(18) Liu, Y.-L.; Chuo, T.-W. Self-healing polymers based on thermally reversible Diels-Alder chemistry. Polym. Chem. 2013, 4, 2194-2205.

(19) Schütz, M. B.; Lê, K.; Ilyas, S.; Mathur, S. Reversible Covalent Assembly of Nanoparticles through On-Surface Diels-Alder Reaction. Langmuir 2020, 36, 1552-1558.

(20) Altinbasak, I.; Sanyal, R.; Sanyal, A. Best Of Both Worlds: DielsAlder Chemistry Towards Fabrication Of Redox-Responsive Degradable Hydrogels For Protein Release. RSC Adv. 2016, 6, 74757-74764.

(21) Chen, X.; Dam, M. A.; Ono, K.; Mal, A.; Shen, H.; Nutt, S. R.; Sheran, K.; Wudl, F. A Thermally Re-Mendable Cross-Linked Polymeric Material. Science 2002, 295, 1698-1702.

(22) Ma, T.; Gao, X.; Dong, H.; He, H.; Cao, X. High-Throughput Generation Of Hyaluronic Acid Microgels Viamicrofluidics-Assisted Enzymatic Crosslinking And/Or Diels-Alder Click Chemistryfor Cell Encapsulation And Delivery. Appl. Mater. Today 2017, 9, 49-59. 
(23) Nimmo, C. M.; Owen, S. C.; Shoichet, M. S. Diels-Alder Click Cross-Linked Hyaluronic Acid Hydrogels for Tissue Engineering. Biomacromolecules 2011, 12, 824-830.

(24) Wei, H.-L.; Yang, J.; Chu, H.-J.; Yang, Z.; Ma, C.-C.; Yao, K. Diels-Alder Reaction In Water For The Straightforward Preparation Of Thermoresponsive Hydrogels. Appl. Polym. Sci. 2011, 120, 974980.

(25) Koehler, K. C.; Anseth, K. S.; Bowman, C. N. Diels-Alder Mediated Controlled Release from a Poly(ethylene glycol) Based Hydrogel. Biomacromolecules 2013, 14, 538-547.

(26) Koehler, K. C.; Alge, D. L.; Anseth, K. S.; Bowman, C. N. A DielsAlder modulated approach to control and sustain the release of dexamethasone and induce osteogenic differentiation of human mesenchymal stem cells. Biomaterials 2013, 34, 4150-4158.

(27) Vieyers, A.; Lam, T.; Guillet, R.; France, G.; Castonguay, A.; Kakkar, A. Combined CuI-Catalysed Alkyne-Azide Cycloaddition and Furan-Maleimide Diels-Alder "Click" Chemistry Approach to Thermoresponsive Dendrimers. Chem. Commun. 2010, 46, 18751877.

(28) Yamashita, S.; Fukushima, H.; Niidome, Y.; Mori, T.; Katayama, Y.; Niidome, T. Controlled-Release System Mediated by a Retro Diels-Alder Reaction Induced by the Photothermal Effect of Gold Nanorods. Langmuir 2011, 27, 14621-14626.

(29) Chen, Y. C.; Lin, K. Y. A.; Lin, C. C.; Lu, T. Y.; Lin, Y. H.; Lin, C. H.; Chen, K. F. Photoinduced Antibacterial Activity Of Nrc03 PeptideConjugated Dopamine/Nano-Reduced Graphene Oxide Against Staphylococcus Aureus. Photochem. Photobiol. Sci. 2019, 18, 24422448.

(30) Oz, Y.; Barras, A.; Sanyal, R.; Boukherroub, R.; Szunerits, S.; Sanyal, A. Functionalization of Reduced Graphene Oxide via ThiolMaleimide "Click" Chemistry: Facile Fabrication of Targeted Drug Delivery Vehicles. ACS Appl. Mater. Interfaces 2017, 9, 34194-34203.

(31) Teodorescu, F.; Quéniat, G.; Foulon, C.; Lecoeur, M.; Barras, A.; Boulahneche, S.; Medjram, M. S.; Hubert, T.; Abderrahmani, A.; Boukherroub, R.; Szunerits, S. Transdermal Skin Patch Based On Reduced Graphene Oxide: A New Approach For Photothermal Triggered Permeation Of Ondansetron Across Porcine Skin. J. Control. Release 2017, 245, 137-146.

(32) Chengnan, L.; Pagneux, Q.; Voronova, A.; Barras, A.; Abderrahmani, A.; Plaisance, V.; Pawlowski, V.; Hennuyer, N.; Staels, B.; Rosselle, L.; Skandrani, N.; Li, M.; Boukherroub, R.; Szunerits, S. Near-Infrared Light Activatable Hydrogels For Metformin Delivery. Nanoscale 2019, 11, 15810-15820.

(33) Otari, S. V.; Kumar, M.; Anwar, M. Z.; Thorat, N. D.; Patel, S. K. S.; Lee, D.; Lee, J. H.; Lee, J.-K.; Kang, J. C.; Zhang, L. Rapid Synthesis And Decoration Of Reduced Graphene Oxide With Gold Nanoparticles By Thermostable Peptides For Memory Device And Photothermal Applications. Sci. Rep. 2017, 7, 10980.

(34) Yadav, V.; Roy, S.; Singh, P.; Khan, Z.; Jaiswal, A. 2D MoS 2 -Based Nanomaterials for Therapeutic, Bioimaging, and Biosensing Applications. Small 2019, 15, 1803706.

(35) Shi, J.; Li, J.; Wang, Y.; Cheng, J.; Zhang, C. Y. Recent Advances In Mos2-Based Photothermal Therapy For Cancer And Infectious Disease Treatment. J. Mater. Chem. B 2020, 8, 5793-5807.

(36) Zou, Q.; Abbas, M.; Zhao, L.; Li, S.; Shen, G.; Yan, X. Biological Photothermal Nanodots Based on Self-Assembly of PeptidePorphyrin Conjugates for Antitumor Therapy. J. Am. Chem. Soc. 2017, 139, 1921-1927.

(37) Chen, G.; Ma, B.; Xie, R.; Li, C.; Dou, K.; Gong, S. CuS-Based Theranostic Micelles for NIR-Controlled Combination Chemotherapy and Photothermal Therapy and Photoacoustic Imaging. ACS Appl. Mater. Interfaces 2017, 9, 41700-41711.

(38) Teirlinck, E.; Barras, A.; Liu, J.; Fraire, J. C.; Lajunen, T.; Xiong, R.; Forier, K.; Li, C.; Urtti, A.; Boukherroub, R.; Szunerits, S.; De Smedt, S. C.; Coenye, T.; Braeckmans, K. Exploring Light-Sensitive Nanocarriers for Simultaneous Triggered Antibiotic Release and Disruption of Biofilms Upon Generation of Laser-Induced Vapor Nanobubbles. Pharmaceutics 2019, 11, 201.
(39) Ahmed, W.; Zhai, Z.; Gao, C. Adaptive Antibacterial Biomaterial Surfaces And Their Applications. Mater. Today Bio 2019, 2, 100017.

(40) Teodorescu, F.; Rolland, L.; Ramarao, V.; Abderrahmani, A.; Mandler, D.; Boukherroub, R.; Szunerits, S. Electrochemically Triggered Release Of Human Insulin From An Insulin-Impregnated Reduced Graphene Oxide Modified Electrode. Chem. Commun. 2015, 51, 14167-14170.

(41) Wenzel, M.; Chiriac, A. I.; Otto, A.; Zweytick, D.; May, C.; Schumacher, C.; Gust, R.; Albada, H. B.; Penkova, M.; Kramer, U.; Erdmann, R.; Metzler-Nolte, N.; Straus, S. K.; Bremer, E.; Becher, D.; Brotz-Oesterhelt, H.; Sahl, H.-G.; Bandow, J. E. Small Cationic Antimicrobial Paptides Delocalized Peripheral Memebrane Proteins. Proc. Natl. Acad. Sci. U. S. A. 2014, 111, E1409-E1418.

(42) Wenzel, M.; Prochonow, P.; Mowbray, C.; Vuong, C.; Hoxtermann, S.; Stepanek, J. J.; Albada, H. B.; Hall, J.; MetzlerNolte, N.; Bandow, J. E. Toards Profiles and Resistance Development and Toxicity for the small cationic hexapeptide RWRWRW- $\mathrm{NH}_{2}$. Front. Cell Dev. Biol. 2016, 4, 86.

(43) Vermonden, T.; Censi, R.; Hennink, W. E. Hydrogels for Protein Delivery. Chem. Rev. 2012, 112, 2853-2888.

(44) Im, I.-T.; Youn, S. B.; Kim, K. Numerical Study on the Temperature Profiles and Degree of Burns in Human Skin Tissue During Combined Thermal Therapy. Numer. Heat Transfer, Part A 2015, 67, 921-933.

(45) Li, C.; Ye, R.; Bouckaert, J.; Zurutuza, A.; Drider, D.; Dumych, T.; Paryzhak, S.; Vovk, V.; Bilyy, R. O.; Melinte, S.; Li, M.; Boukherroub, R.; Szunerits, S. Flexible Nanoholey Patches for Antibiotic-Free Treatments of Skin Infections. ACS Appl. Mater. Interfaces 2017, 9, 36665-36674.

(46) Altinbasak, I.; Jijie, R.; Barras, A.; Golba, B.; Sanyal, R.; Bouckaert, J.; Drider, D.; Bilyy, R.; Dumych, T.; Paryzhak, S.; Vovk, V.; Boukherroub, R.; Sanyal, A.; Szunerits, S. Reduced Graphene Oxide Embedded PolymericNanofiber Mats: An "On-Demand"Photothermally-Triggered Antibiotic Release Platform. ACS Appl. Mater. Interfaces 2018, 10, 41098-41106. 